IZADP No. 2929

Heterogeneity in Real Wage Cyclicality

Pedro S. Martins

July 2007 


\title{
Heterogeneity in Real Wage Cyclicality
}

\author{
Pedro S. Martins \\ Queen Mary, University of London, \\ CEG-IST Lisbon and IZA
}
Discussion Paper No. 2929 July 2007

IZA

P.O. Box 7240

53072 Bonn

Germany

Phone: +49-228-3894-0

Fax: +49-228-3894-180

E-mail: iza@iza.org

\begin{abstract}
Any opinions expressed here are those of the author(s) and not those of the institute. Research disseminated by IZA may include views on policy, but the institute itself takes no institutional policy positions.

The Institute for the Study of Labor (IZA) in Bonn is a local and virtual international research center and a place of communication between science, politics and business. IZA is an independent nonprofit company supported by Deutsche Post World Net. The center is associated with the University of Bonn and offers a stimulating research environment through its research networks, research support, and visitors and doctoral programs. IZA engages in (i) original and internationally competitive research in all fields of labor economics, (ii) development of policy concepts, and (iii) dissemination of research results and concepts to the interested public.
\end{abstract}

IZA Discussion Papers often represent preliminary work and are circulated to encourage discussion. Citation of such a paper should account for its provisional character. A revised version may be available directly from the author. 


\section{ABSTRACT}

\section{Heterogeneity in Real Wage Cyclicality ${ }^{*}$}

This paper presents evidence that real wage cyclicality can be a particularly heterogeneous parameter, depending on different worker characteristics and also on the specific stage of the business cycle. Using matched employer-employee panel data for Portugal covering the period 1986-2004, real wages are shown to be considerably more procyclical during recessions than during expansions, resulting in relatively moderate overall levels of cyclicality (about -0.6). However, most of the procyclicality during downturns is shown to be driven by the younger employees, as older workers appear to be insulated from the business cycle. Moreover, movers between firms typically display higher cyclicality than workers that stay in the same firm, regardless of whether the latter move or not between job levels. Most results also hold when considering basic wages instead of total wages, except that the procyclicality of movers during downturns is substantially higher.

JEL Classification: J31, E24, E32

Keywords: matched employer-employee data, worker mobility, wage rigidity

Corresponding author:

Pedro S. Martins

School of Business and Management

Queen Mary, University of London

Mile End Road

London E1 4NS

United Kingdom

E-mail: p.martins@qmul.ac.uk

\footnotetext{
*I thank, without implicating, Paul Devereux, Bob Hart, Pedro Portugal, and Jonathan Thomas for their useful comments. Research support from the ESRC (RES-062-23-0546) and logistical support from Banco de Portugal are gratefully acknowledged. The data used in this paper are confidential but the author's access is not exclusive.
} 


\section{Introduction}

There is now considerable evidence that real wage procyclicality is an important feature of labour markets (Bils 1985, Solon et al. 1994, Abraham \& Haltiwanger 1995, Devereux 2001, Devereux \& Hart 2006). After a relatively long period in which wages were perceived as relatively acyclical or even countercyclical, research based on longitudinal micro data has concluded that times of expansion (contraction) are systematically related to higher (lower) wages for the same individuals.

However, although much research about different facets of labour markets highlights the role of heterogeneity, at both the worker- and the firm-levels (Abowd et al. 1999), relatively little is known about how the sensitivity of individual wages to the business cycle varies with worker characteristics. This is probably an important oversight. Moreover, as the most recent wage cyclicality studies highlight the role of compositional differences over the business cycle, there is an implicit understanding that worker characteristics need to be taken into account ${ }^{1}$

In this paper we seek to understand how representative of an entire labour market can a single, average real wage cyclicality estimate be. To begin with, our analysis considers different dimensions across which wage cyclicality may vary, including whether workers stay in the same job, move across jobs in the same firm, or move across firms (Devereux \& Hart 2006, Hart 2006). Indeed, job stayers may hold job- and/or firm-specific capital that generates a wedge between the value of their job for the firm and the worker's outside opportunity. This wedge will then create scope for a buffer that may attenuate the link between the business cycle and the worker's pay. However, workers that move between jobs, particularly those that move to different firms, are liable to be subject to much greater exposure to the external labour market and therefore to the business cycle.

Another dimension we consider concerns workers' gender and age. Gender and age are well-known important determinants of the wage structure and may also be strongly correlated to differences across workers in terms of their bargaining power. In particular, older workers are likely to be more protected against downturns in the labour market, particularly in the context of stringent employment protection laws (Lazear 1990), as they tend to be biased in favour of high-tenure workers. To that extent, one may expect that real wage cyclicality estimates are disproportionately driven by young workers.

\footnotetext{
1 Ziliak et al. (1999) is the only study we know of that also seeks to address the topic of the heterogeneity in real wage cyclicality, finding significant differences across races and union status.
} 
Different measures of pay are also a potentially important dimension that can generate heterogeneity in real wage cyclicality estimates (Shin \& Solon 2007, Swanson 2007). For instance, total pay typically includes different categories that may exhibit different levels of sensitivity to the business cycle - e.g. bonuses or overtime pay may be much more easily adusted than base pay. However, one may also argue that the shares of fixed and flexible pay may change themselves over the business cycle, perhaps if firms prefer to have greater control over their wage bill in more uncertain times.

Finally, we also consider differences not in terms of worker characteristics but in terms of the specific phase of the business cycle. This analysis is motivated by the findings of Beaudry \& DiNardo (1991), which present evidence that individual wages in the U.S. tend to be pushed upwards during boom years but not pushed downwards during slumps. As far as we know, this finding has not been tested from the point of view of the real wage cyclicality literature, although that asymmetry result would presumably predict that most wage cyclicality estimates are driven by wage increases in periods of expansion, and not by wage cuts or lower wage growth in periods of recession.

The breadth of the empirical analysis carried out in this paper is possible due to the richness of our data, a particularly comprehensive matched employer-employee panel data set. These data, 'Quadros de Pessoal', cover the universe of firms based in Portugal that employ at least one employee in at least one year. At the worker level, the data also cover, on an individual basis, all employees of each firm in each year. The time period considered here is also relatively large, ranging from 1986 to 2004, which corresponds to almost two full business cycles. Moreover, the Portuguese economy perhaps also provides an interesting contrast to the cases of the US and the UK - which have received most of the attention so far - namely due to its combination of stringent employment protection legislation and relatively low unemployment rates (Blanchard \& Portugal 2001, Varejao \& Portugal 2007).2

We find that, as suggested above, different workers experience the business cycle in (considerably) different ways. In particular, the wages of the younger workers and of those that move across employers tend to undergo particularly lower growth rates during downturns.

\footnotetext{
${ }^{2}$ Indeed, Carneiro \& Portugal (2007) also examine real wage cyclicality using similar 'Quadros de Pessoal' data, focusing on the role of 'stayers', 'accessions' (defined as workers in any given year that appear in a firm for the first time) and 'separations' (defined as workers in any given year that appear in a firm for the last time). However, there are several methodological differences between the two papers that make the comparison of their results difficult. We come back to the findings of Carneiro \& Portugal (2007) when we discuss our results, in section 3.4
} 
However, such asymmetries across workers are not observed during periods of expansion. Moreover, we also find that movers between firms (unlike movers within firms or stayers in the same firm and job level) are very sensitive to such downturns, especially in terms of their basic wages.

The remaining of the paper is as follows: Section 2 presents the original data source and the construction of the data set used in our analysis; Section 3 presents and discusses the results; and Section 4 concludes.

\section{Data}

As mentioned above, this paper draws on 'Quadros de Pessoal' (QP), a particularly rich annual census of all firms based in Portugal that employ at least one worker. In this census, conducted and administered by the Ministry of Employment, each firm provides extensive information about the firm itself and also about each one of their workers employed at the census reference month (March up to 1993 and October from 1994).

The extensive coverage of 'Quadros de Pessoal' implies that the only workers not present in the data are the self-employed and those employed in the public sector. (Of course, the unemployed and the inactive are also not included.) Moreover, the period covered by the data is also relatively long, from 1986 to 2004 (except 1990 and 2001, which are years when the census was not carried out) $!^{3}$ Over these 17 years, there are, on average, about 2.5 million workers and 220,000 firms in each year, and a total of about 600,000 different firms.

The long list of variables available in the data includes unique identifiers for each firm and each employee. These identifier variables allow us to follow workers over time and, in particular, as they move between firms. Other firm-level variables include industry (5-digit code), region (up to 400 different units), number of employees, firm age, public, private/domestic or foreign ownership, sales, and equity. At the worker-level, the data make available information about schooling, age, gender, tenure, occupation (5-digit code), wages, hours worked, job level and promotions.

There are several wage variables, all of them expressed in monthly values (the most common type of pay in Portugal), including base wages, tenure-related payments, overtime pay, subsidies and 'other payments' (this latter category includes bonuses and profit-

\footnotetext{
${ }^{3}$ The years of 1982 to 1985 are also available but they do not include a unique worker identifier, thus compromising the panel analysis pursued in this paper.
} 
or performance-related pay). All wages have been deflated using Portugal's CPI and are expressed in 2004 euros. There is also information about normal hours and overtime hours per month. The benchmark measure of pay adopted in this study is based on the sum of all five types of pay divided by the sum of the two types of hours worked, resulting in a measure of total hourly pay.

We created the data files used in our analysis by considering only workers observed in years $t$ and $t-1$ ( $t$ ranging from 1987 to 2004) ${ }^{4}$ We also made sure that the same workers were compared by requiring that each pair of observations for each identifier had the same year of birth, month of birth and gender. Finally, we also dropped all identifiers that appeared more than once in each year, thus removing from our analysis workers that hold multiple jobs (a relatively small group in any case, as most jobs are full time) or miscoded individual identifiers.

We separated the resulting data intro three groups of workers: those that stay in the same firm and in the same job level (which we label as 'stayers'), those that stay in the same firm but in a different job level ('within-firm movers') and those that move to a different firm ('betweenfirm movers') $5^{5}$ Workers that move between firms but whose date of entry (month and year) into the second firm is the same as the date of entry into the first firm are dropped - these workers are probably moving across firms that belong to the same holding or conglomerate group or are employed by firms that were subject to mergers or acquisitions. The job-level variable used for the distinction between 'stayers' and 'within-firm movers' is based on the hierarchical level categories indicated by the Ministry of Employment. We considered the one-digit version of this job-level variable, in which there are nine different categories, ranging from top managers (category 1) to apprentices (category 9).

Table A.1 describes the three groups of data. There are over 13 million observations (workers-year) in the first group (stayers in the same firm and job level), approximately 2.4 million observations in the second group (stayers in the same firm but moving between job levels), and about 1.1 million observations in the third category (movers between firms).

There are some important differences across the three groups. For instance, tenure levels are highest for firm/job-level stayers (an average of 10.6 years) and lowest for movers (an

\footnotetext{
${ }^{4}$ In the cases of 1991 and 2002, we considered the years of 1989 and 2000, respectively, as $t-1$. Recall that the data for 1990 and 2001 were not collected by the Ministry of Employment.

${ }^{5}$ See also Martins 2006) for another analysis of worker mobility across firms using the 'Quadros de Pessoal' data set.
} 
average of 0.3 years) - by construction, the latter group will have an average tenure of less than one year. Movers are also the youngest across the three groups; they also hold the lower level jobs and earn the lower wages. Average growth rates of wages are $4 \%$ for firm/job-level stayers, while the two remaining groups gain an average growth rate of between $7 \%$ and $8 \% .6$

Finally, the business cycle information is obtained from the labour market statistics published by the OECD. Figures 1 and 2 describe the evolution of unemployment rates for each one of the five age categories, over the period covered, for men and women, respectively. One can observe that the period includes almost two complete business cycles: the first running from 1986 (after the end of the recession of 1983) to 1995 (the end of the recession of 1993) and the second from 1995 to 2004 (the end of the recession of 2003). Among other results, we find that men tend to exhibit lower unemployment rates than women. Moreover, the younger cohorts, particularly the cohort aged 15-24, tend to display the highest and most variable unemployment rates.

\section{Results}

\subsection{Methodology}

Our empirical analysis uses the now standard two-step estimation procedure (Solon et al. 1994). This procedure is designed to address the problem identified by Moulton (1986) and others that individuals in the same year will share some common component of variance that is not entirely attributable either to their measured characteristics (e.g. gender) or to the aggregate unemployment rate in that year. In this case, the error component in simple OLS regression will be positively correlated across people in the same year, which would underestimate the standard error on the unemployment variable.

In the first step of our analysis, we estimate the following first-differenced wage equation, based on individual-level data:

$$
\Delta w_{i j t}=\beta_{j 0}+\beta_{j 1} A_{g e_{i t}}+\beta_{j 2} E d u c_{i t}+\sum_{t=1}^{T} \phi_{j t} D_{t}, \quad(j=1,2, \ldots, 30),
$$

in which $i$ refers to each individual's unique identifier; $j$ concerns the group of the worker, defined in terms of the worker's age group (15 to 24,25 to 34,35 to 44,45 to 54 , and 55 to 64 ),

\footnotetext{
${ }^{6}$ We also observe a clearly procyclical pattern in the number of movers between firms, which is consistent with Shimer (2005).
} 
gender, and mobility type ('stayer', 'within-firm mover', and 'across-firm mover'), resulting in 30 age-gender-mobility 'cells'; $D_{t}$ is a binary variable equal to 1 if the period of the observation is year $t$; $\Delta w_{i j t}$ is the difference in the log wage rates of worker $i$ (of 'cell' $j$ ) between years $t$ and $t-1$; and $A g e_{i t}$ and $E d u c_{i t}$ are, respectively, the individual's age and schooling level in period $t: 7$

In the second step, the sets of estimated binary variable coefficients obtained from equation 1 . $\widehat{\phi_{j t}}$, are regressed separately on the change in unemployment over the same time period and on a time trend:

$$
\widehat{\phi_{j t}}=\delta_{j 0}+\delta_{j 1} \Delta U_{j t}+\delta_{j 2} t+v_{j t}, \quad(j=1,2, \ldots, 30) .
$$

Moreover, these second-stage regressions are weighted to reflect the number of individuals observed in a given year. Overall, our methodology follows closely that of Devereux \& Hart (2006) or Hart (2006), except that we run separate first-stage regressions for each one of our 'cells', while those two papers use the same first-differenced wage equation for different cells, adding interaction terms to capture the difference across cells.

Finally, as indicated in Section 1, we consider two different measures of wages: total real wages and basic real wages. Both wages are measured in hourly terms. Moreover, for each wage measure, we also consider different versions of equation 2, including additional terms that aim to capture possible evidence of heterogeneity in the impact of the business cycle across different groups of workers and/or different stages of the business cycle.

\subsection{Estimates}

As explained above, the second-stage results that will be presented next are obtained first from pooling all the coefficients for each year dummy variables in each 'cell' regression. Second, we regress those sets of year-dummy coefficients on a variable capturing the change in unemployment for that 'cell' of workers over the same year and on a trend. In the case of specifications 2 to 8 in Table 1, additional variables are included in this second-stage regression, such as an interaction between the change in unemployment and a female dummy variable (column 2). This interaction thus provides evidence about any additional effect that the business cycle

\footnotetext{
7 Devereux \& Hart (2006) and Hart (2006) do not control for schooling, a variable not available in their data set. We include it here as there is considerable evidence of steeper wage profiles for more educated workers and we want to control for the role of that in explaining wage differences.
} 
may have for women.

The first and main set of results, based on total real wages, are presented in Table 1 . Column 1 indicates a very significant but relatively low level of real wage cyclicality, at -0.558 . This estimate indicates that for each one percentage point increase in the unemployment rate there is a $0.6 \%$ decrease in wages. Moreover, there is no significant evidence of differences in cyclicality across genders (column 2), as documented by the coefficient on the interaction between the change in the unemployment rate and a 'Female' dummy variable.

We now test whether real wages change differently during different parts of the business cycle. We consider a second-stage specification modified from equation 2 so to include an interaction between the change in the unemployment rate and a dummy for periods in which the unemployment rate increases $\left(\Delta U^{+}\right)$:

$$
\widehat{\phi_{j t}}=\delta_{j 0}+\delta_{j 1} \Delta U_{j t}+\delta_{j 2} \Delta U_{j t}^{+}+\delta_{j 3} t+v_{j t} .
$$

This new equation allows us to assess if the earlier evidence on real wage cyclicality is equally driven from lower wage growth during downturns and higher wage growth during expansions. We find that $\delta_{j 2}$, the coefficient that captures any possible asymmetries over the business cycle becomes very large and significant (column 3). Furthermore, the coefficient for the general business cycle term $\left(\delta_{j 1}\right)$ is now insignificant. Taken at face value, these results indicate that real wage cyclicality is driven uniquely by relatively lower wage increases in periods of downturn, rather than by a balanced combination of wage changes over the entire business cycle.

Another topic of interest concerns the possible differences in the role cyclicality across stayers and movers. In order to shed light on this question, we consider another modified version of equation 2, augmented with dummy variables capturing any possible differences between the two types of movers with respect to the comparison group of stayers:

$$
\widehat{\phi_{j t}}=\delta_{j 0}+\delta_{j 1} \Delta U_{j t}+\delta_{j 2} \text { Mover } 1_{j}+\delta_{j 3} \text { Mover } 2_{j}+\delta_{j 4} t+v_{j t} .
$$

Column 4 presents the results. While the point estimates suggest that movers are more sensitive to the business cycle (particularly movers across firms), none of the coefficients is significantly different from zero. Similar results are displayed in column 5, which considers 
differences in real wage cyclicality for different age groups. The point estimates increase with the age group, eventually becoming even bigger than the main coefficient about the change in unemployment, but none of those age group coefficients is significantly different from zero.

In the last three sets of estimates, we investigate if there are any interactions between, on the one hand, differences in the sensitivity of wages to the business cycle in periods of expansion and periods of downturn and, on the other hand, worker characteristics. In column 6 , we consider an interaction between the change in the unemployment rate and periods in which the unemployment rate increase $\left(\Delta U^{+}\right)$, allowing for differences in the impact of that interaction for different mobility groups:

$$
\widehat{\phi_{j t}}=\delta_{j 0}+\delta_{j 1} \Delta U_{j t}+\delta_{j 2} \text { Mover } 1_{j} * \Delta U_{j t}^{+}+\delta_{j 3} \text { Mover } 2_{j} * \Delta U_{j t}^{+}+\delta_{j 4} t+v_{j t} .
$$

For this specification, we find that, while the main interaction remains highly significant and with a similar size as in column 3 (a coefficient of -1.534), $\widehat{\delta_{j 3}}$, the coefficient on the interaction between $\left(\Delta U^{+}\right)$and workers that move across firms $\left(\right.$Mover $\left.2_{j}\right)$ is now significantly negative and considerably large (-1.340). In other words, we find evidence that downturns in the business cycle are significantly related to lower wage growth rates while periods of expansion are not significantly connected to higher wage growth rates. Moreover, across the three types of worker mobility we consider (stayers in the same job and firm; movers across jobs in the same firm; and movers across firms), the latter are significantly more sensitive to such downturns in the macroeconomy.

In the last two columns of Table 1, we consider the differences across age groups in the sensitivity of their pay with respect to the business cycle. Column 7 presents evidence that the asymmetric effect of the business cycle differs across age groups. Such effect is particularly negative for the comparison group (workers aged 15-24), with a coefficient of the $\Delta U^{+}$ interaction of -2.574 . For the other age groups, that very strong negative effect is attenuated by the positive coefficients of the interactions between $\Delta U^{+}$and each respective age group dummy. However, only for the oldest age group, those aged 55-64, is that interaction greater than the simple $\Delta U^{+}$interaction. In other words, all age groups exhibit lower wage growth during downturns except the most senior employees.

A similar result is documented when one includes interactions between the change in the unemployment rate and the age groups on top of the $\Delta U^{+}$interaction and the interactions 
between $\Delta U^{+}$and the age group dummy variables (column 8 ). The advantage of this specification is that it also provides evidence about the differences in real wage cyclicality in periods of macroeconomic expansion (as measured by decreasing unemployment rates).

The results from this specification reinforce our findings of overall relatively modest levels of real wage cyclicality, even for the older workers, during periods of expansion - ranging from -0.6 for the workers in the 25-34 age group to -1.3 for the workers in the $45-54$ age group 8 Finally, the evidence about periods of downturn still indicates very pronounced decreases in wage growth for the younger, while the older are relatively insulated from the cycle and may even exhibit countercyclical wages.

\subsection{Robustness}

Finally, we are also interested in assessing the robustness of these findings, while also considering possible differences related to different measures of the wage variable. Table 2 presents evidence about real wage cyclicality considering only basic wages, rather than total wages as in the previous table.

The results across the two tables are particularly similar, with two exceptions only. The first exception concerns the differences in wage cyclicality for movers vs. stayers (column 4). Unlike with total wages, we find that movers across firms exhibit greater wage cyclicality (regardless of the stage of cycle) than stayers or movers within firms.

The other exception concerns again the differences between movers and stayers, this time in terms of its asymmetries over the business cycle. Column 6 indicates that movers across firms in periods of downturn endure particularly lower wage growth rates in terms of their basic pay, something which we did not observe when considering total pay.

\subsection{Discussion}

One important aspect of our results concerns their contrast with those of Beaudry \& DiNardo (1991). As mentioned before, that paper presents evidence that workers tend to be protected against negative shocks while they benefit from positive shocks to their firms. In our results, we find precisely the opposite type of asymmetry: while periods of expansion are characterised by few wage growth increases, downturns tend to be associated with considerable wage growth

\footnotetext{
${ }^{8}$ These numbers are obtained from subtracting the $\Delta U$ coefficient from the coefficient of each $\Delta U *$ agegroup interaction in column 8 of Table 1 .
} 
decreases.

However, we also found that such decreases in wage growth during downturns are almost uniquely concentrated with the younger workers. This result may be related to the stringent employment protection legislation in Portugal and its consequences in terms of a relatively segmented labour market. In fact, given the large role played by tenure and/or age in terms of greater employment protection, older workers may easily become insiders insulated from the business cycle. Conversely, younger workers bear the brunt of the adjustments required by adverse economic shocks. Young workers are also those that tend to be less protected by unemployment benefits, which further erodes their bargaining power 9

On the other hand, our findings about worker heterogeneity in terms of whether they stay in the same firm or move between firms are more directly in line with previous, comparable evidence (Barlevy 2001, Devereux \& Hart 2006, Hart 2006). We found a similar 'ranking' of different sensitivity levels with respect to the business cycle, in which stayers in the same occupation in the same firm are the least sensitive and movers between firms are the most sensitive.

However, statistically significant differences could only be found between movers between firms and the two remaining categories of workers, not between the two types of 'stayers' (remaining at the same job level or moving across job levels in the same firm). One question left for further research is if the lack of statistically significant differences between the latter two categories is related to the choice of a job-level variable to indicate mobility within the firm, instead of an occupation-related measure.

Moreover, even the differences between movers and stayers were only detectable when focusing on periods of increasing unemployment rates. This finding is probably due to the greater degree of worker self-selection in mobility decisions during periods of expansion, contrasting to the much higher amount of employer-induced separations during downturns. The latter layoffs are likely to force workers to take jobs where they cannot take advantage of the occupation- or industry-specific skills they accumulated at their previous job.

One additional result that deserves discussion is the greater procyclicality of movers between firms when measuring wages only in terms of basic pay (rather than when using total pay, which we took as our benchmark results). Besides indicating that base pay is particularly

\footnotetext{
${ }^{9}$ Using a sub-sample of the data used here, complemented with firm-level measures of 'rents', Martins (2004) presents evidence of less rent sharing for low-tenure workers.
} 
sensitive to downturns, the result also suggests that the sum of the remaining components of total compensation (including performance-related pay) are relatively less sensitive to the business cycle.

While this last finding certainly deserves greater attention in future research, one possible explanation is that firms adjust the relative importance of fixed and variable pay over the business cycle and/or that the pay profiles of jobs (in terms of the shares of fixed and variable compensation) vary over the business cycle. For instance, workers that leave their firms during downturns may be forced to take considerable basic pay cuts in their new jobs but are in part compensated by relatively more generous rewards in their variable pay components. This process of adjustment would be consistent with the evidence documented here of greater cyclicality in downturns when considering basic wages instead of total wages.

When compared to the results in Carneiro \& Portugal (2007) (CP, henceforth), our findings indicate reasonably lower levels of real wage cyclicality (our benchmark result is -0.6 while CP's is about -1). However, it is difficult to pinpoint a single specific explanation behind this difference as the two studies differ in several dimensions: First, we extend CP's coverage from 1986-1998 to 1986-2004. Second, except in the case of stayers, CP pool cross-section samples of 'accessions' and 'separations', while we link the wages of each individual before and after they change jobs. Finally, and perhaps most important, CP examine the relationship between wages and unemployment in a single step, while we adopt the two-step method discussed above.

\section{Conclusions}

This paper presents evidence that wage cyclicality can be a particularly heterogeneous parameter. Using matched employer-employee panel data for Portugal covering the period 1986-2004, real wages are shown to be substantially procyclical during recessions while only moderately procyclical during expansions, resulting in relatively moderate overall levels of cyclicality (around -0.6).

However, most of the procyclicality during recessions is driven by the younger employees, as older workers appear to be insulated from the business cycle. Moreover, movers between firms typically display higher wage cyclicality than stayers or movers between job levels in the same firm. Most results also hold when considering basic wages, except that the procyclicality 
of movers across firms during downturns is higher than when considering total wages.

In general, the labour market studied here can be characterised by a moderate average level of flexibility, although, as mentioned above, that average flexibility masks considerable asymmetries across workers and time periods. In any case, such ability to adjust probably explains why unemployment rates have typically remained rather low over the two business cycles that are examined here. However, it remains to be seen if this degree of flexibility is large enough to address the current macroeconomic imbalances that affect Portugal, namely in terms of its current account. Similar challenges are faced by other eurozone countries.

\section{References}

Abowd, J. M., Kramarz, F. \& Margolis, D. N. (1999), 'High wage workers and high wage firms', Econometrica 67(2), 251-334.

Abraham, K. G. \& Haltiwanger, J. C. (1995), 'Real wages and the business cycle', Journal of Economic Literature 33(3), 1215-1264.

Barlevy, G. (2001), 'Why are the wages of job changers so procyclical?', Journal of Labor Economics 19(4), 837-78.

Beaudry, P. \& DiNardo, J. (1991), 'The effect of implicit contract on the movement of wages over the business cycle: Evidence from micro data', Journal of Political Economy 99(4), 665-688.

Bils, M. (1985), 'Real wages over the business cycle: Evidence from panel data', Journal of Political Economy 93(4), 666-687.

Blanchard, O. \& Portugal, P. (2001), 'What hides behind an unemployment rate: Comparing Portuguese and U.S. labor markets', American Economic Review 91(1), 187-207.

Carneiro, A. \& Portugal, P. (2007), Workers' flows and real wage cyclicality, IZA DP 2604.

Devereux, P. (2001), 'The cyclicality of real wages within employer-employee matches', Industrial and Labor Relations Review 54(4), 835-850.

Devereux, P. \& Hart, R. (2006), 'Real wage cyclicality of job stayers, within-company 
job movers, and between-company job movers', Industrial and Labor Relations Review 60(1), 105-119.

Hart, R. (2006), 'Worker-job matches, job mobility and real wage cyclicality', Economica 73(290), 287-298.

Lazear, E. P. (1990), 'Job security provisions and employment', Quarterly Journal of Economics 105(3), 699-726.

Martins, P. (2004), Rent sharing before and after the wage bill, IZA DP 1376.

Martins, P. (2006), Inter-firm worker mobility, wages and foreign direct investment spillovers, mimeo, Queen Mary, University of London.

Moulton, B. (1986), 'Random group effects and the precision of regression estimates', Journal of Econometrics 32(3), 385-397.

Shimer, R. (2005), 'The cyclicality of hires, separations, and job-to-job transitions', Federal Reserve Bank of St. Louis Review (Jul), 493-508.

Shin, D. \& Solon, G. (2007), 'New evidence on real wage cyclicality within employer-employee matches', Scottish Journal of Political Economy.

Solon, G., Barsky, R. \& Parker, J. (1994), 'Measuring the cyclicality of real wages: How important is composition bias', Quarterly Journal of Economics 109(1), 1-25.

Swanson, E. (2007), 'Real wage cyclicality in the PSID', Scottish Journal of Political Economy.

Varejao, J. \& Portugal, P. (2007), 'Employment dynamics and the structure of labor adjustment costs', Journal of Labor Economics 25(1), 137-166.

Ziliak, J., Wilson, B. \& Stone, J. (1999), 'Spatial dynamics and heterogeneity in the cyclicality of real wages', Review of Economics and Statistics 81(2), 227-236. 
Figure 1: Unemployment Rates, Men, Portugal, 1987-2005

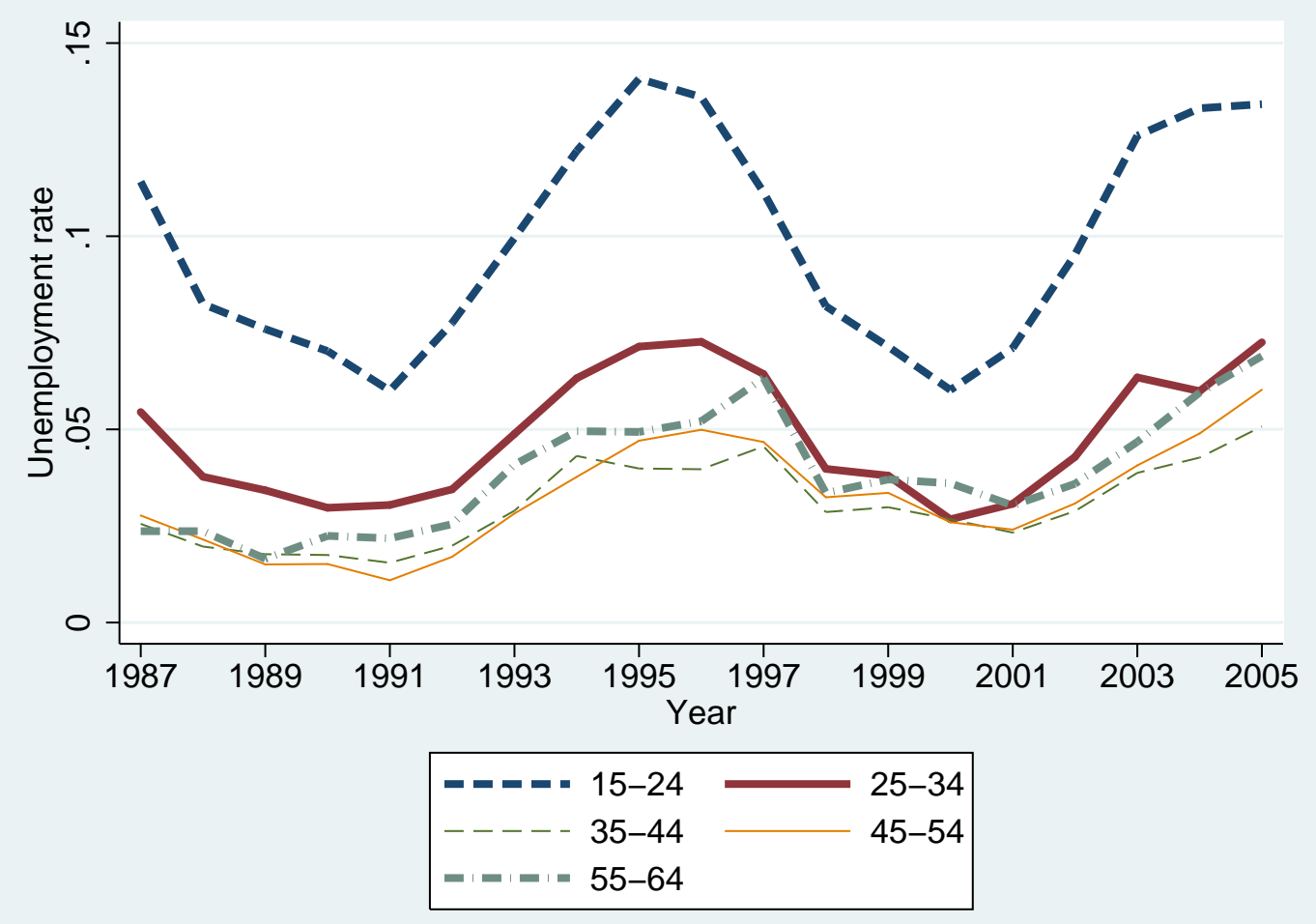

Source: Author's calculations based on OECD data. 
Figure 2: Unemployment Rates, Women, Portugal, 1987-2005

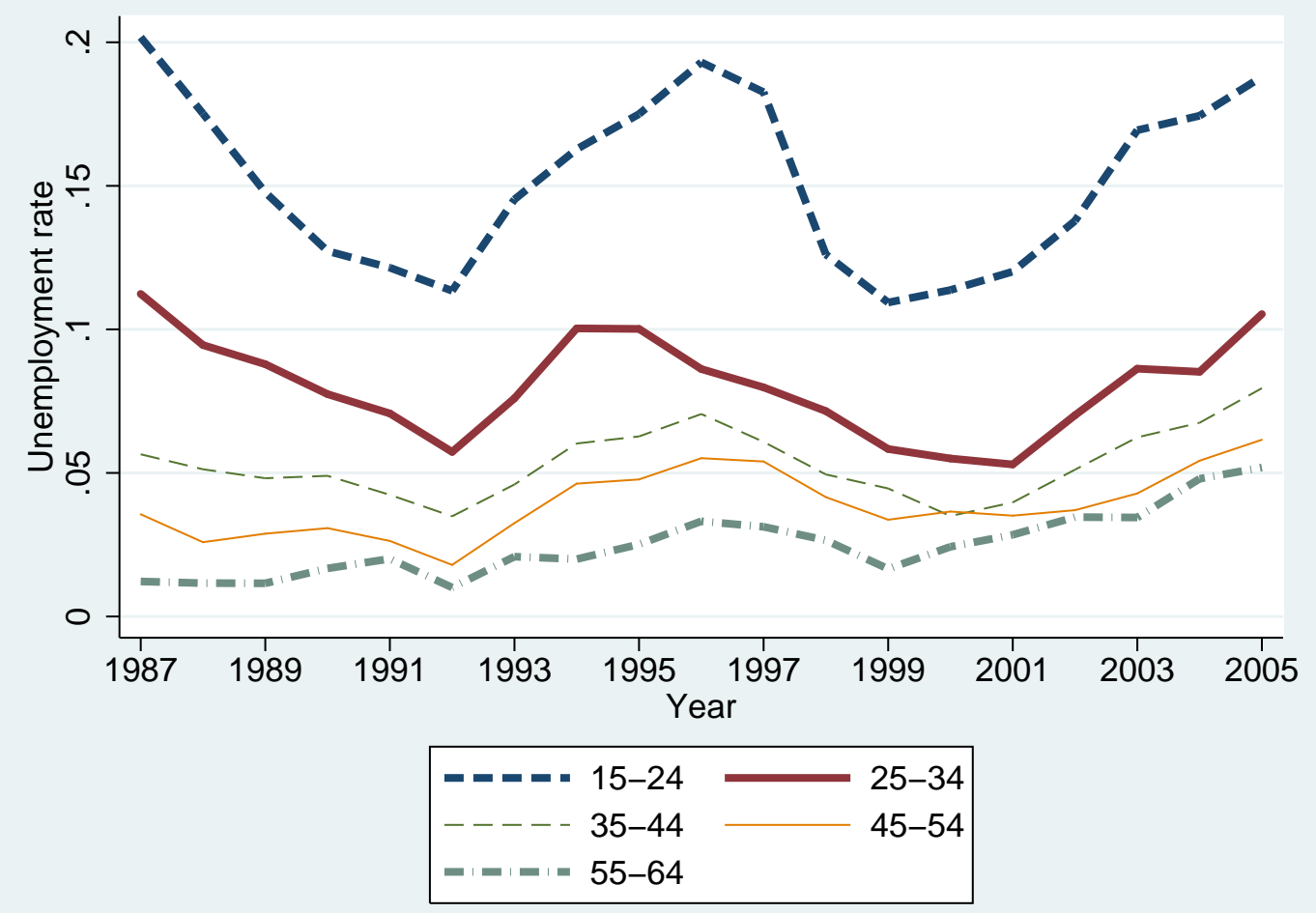

Source: Author's calculations based on OECD data. 
Table 1: Real Wage Cyclicality (Total Wages)

\begin{tabular}{|c|c|c|c|c|c|c|c|c|}
\hline & 1 & 2 & 3 & 4 & 5 & 6 & 7 & 8 \\
\hline \multirow[t]{2}{*}{$\Delta U$} & $-0.558^{* * *}$ & $-0.623^{* * *}$ & 0.315 & $-0.450^{* *}$ & $-0.650^{* *}$ & 0.293 & 0.102 & $0.738^{* * *}$ \\
\hline & {$[0.153]$} & [0.192] & {$[0.276]$} & {$[0.190]$} & {$[0.298]$} & {$[0.277]$} & {$[0.290]$} & {$[0.279]$} \\
\hline \multirow[t]{2}{*}{$\Delta U^{*} \mathrm{Fem}$} & & 0.138 & & & & & & \\
\hline & & [0.311] & & & & & & \\
\hline \multirow[t]{2}{*}{$\Delta U^{+}$} & & & $-1.777^{* * *}$ & & & $-1.534^{* * *}$ & $-2.574^{* * *}$ & $-3.039 * * *$ \\
\hline & & & {$[0.455]$} & & & {$[0.488]$} & [0.439] & {$[0.411]$} \\
\hline \multirow[t]{2}{*}{$\Delta U^{*} \operatorname{Mob} 2$} & & & & -0.228 & & & & \\
\hline & & & & [0.348] & & & & \\
\hline \multirow[t]{2}{*}{$\Delta U^{*}$ Mob3 } & & & & -0.735 & & & & \\
\hline & & & & {$[0.457]$} & & & & \\
\hline \multirow[t]{2}{*}{$\Delta U^{*}$ Age 2} & & & & & 0.062 & & & $-1.363^{* * *}$ \\
\hline & & & & & {$[0.384]$} & & & {$[0.506]$} \\
\hline \multirow{2}{*}{$\Delta U^{*}$ Age3 } & & & & & 0.109 & & & $-1.907 * * *$ \\
\hline & & & & & {$[0.472]$} & & & {$[0.585]$} \\
\hline \multirow[t]{2}{*}{$\Delta U^{*}$ Age 4} & & & & & 0.078 & & & $-2.075^{* * *}$ \\
\hline & & & & & {$[0.560]$} & & & [0.760] \\
\hline \multirow[t]{2}{*}{$\Delta U^{*}$ Age 5} & & & & & 0.911 & & & $-1.688^{* * *}$ \\
\hline & & & & & {$[0.651]$} & & & [0.314] \\
\hline \multirow[t]{2}{*}{$\Delta U^{+*} \operatorname{Mob} 2$} & & & & & & -0.424 & & \\
\hline & & & & & & {$[0.382]$} & & \\
\hline \multirow[t]{2}{*}{$\Delta U^{+*}$ Mob3 } & & & & & & $-1.340 * * *$ & & \\
\hline & & & & & & {$[0.438]$} & & \\
\hline \multirow[t]{2}{*}{$\Delta U^{+*}$ Age 2} & & & & & & & $1.701^{* * *}$ & $3.137^{* * *}$ \\
\hline & & & & & & & {$[0.352]$} & [0.634] \\
\hline \multirow[t]{2}{*}{$\Delta U^{+*}$ Age3 } & & & & & & & $1.956^{* * *}$ & $4.104^{* * *}$ \\
\hline & & & & & & & {$[0.483]$} & {$[0.777]$} \\
\hline \multirow[t]{2}{*}{$\Delta U^{+*}$ Age 4} & & & & & & & $1.926^{* * *}$ & $4.290^{* * *}$ \\
\hline & & & & & & & {$[0.661]$} & [1.052] \\
\hline \multirow[t]{2}{*}{$\Delta U^{+*}$ Age 5} & & & & & & & $3.459 * * *$ & $5.363^{* * *}$ \\
\hline & & & & & & & {$[0.620]$} & {$[0.722]$} \\
\hline$R^{2}$ & 0.114 & 0.115 & 0.154 & 0.12 & 0.119 & 0.165 & 0.214 & 0.25 \\
\hline
\end{tabular}

Notes: The coefficients reported result from the second-stage regression, which used the estimated coefficients of year dummies in a wage growth equation (the first stage). In the second stage, the year dummies are regressed on the variables listed plus a trend. 450 observations are used. $\Delta U$ denotes the change in the unemployment rate with respect to the previous year; $\Delta U^{+}$denotes the interaction between $\Delta U$ and a dummy variable taking value one in years in which the unemployment rate increases; Fem is a dummy for women; Mob2 is a dummy for movers within a firm; Mob3 is a dummy for movers between firms; and Age 2 denotes workers aged between 25 and 34 (Age3 35 and 44; Age 4 - 45 and 54; Age 5 - 55 and 64). Significance levels: *: 0.10; **: 0.05; ***: 0.01. Robust standard errors. 
Table 2: Real Wage Cyclicality (Basic Wages)

\begin{tabular}{|c|c|c|c|c|c|c|c|c|}
\hline & 1 & 2 & 3 & 4 & 5 & 6 & 7 & 8 \\
\hline \multirow[t]{2}{*}{$\Delta U$} & $-0.596 * * *$ & $-0.621 * * *$ & 0.34 & $-0.467^{* *}$ & $-0.704^{* *}$ & 0.308 & 0.096 & $0.746^{* * *}$ \\
\hline & {$[0.157]$} & [0.207] & {$[0.275]$} & {$[0.197]$} & {$[0.296]$} & {$[0.276]$} & {$[0.288]$} & {$[0.249]$} \\
\hline \multirow[t]{2}{*}{$\Delta U^{*} \mathrm{Fem}$} & & 0.054 & & & & & & \\
\hline & & {$[0.320]$} & & & & & & \\
\hline \multirow[t]{2}{*}{$\Delta U^{+}$} & & & $-1.904^{* * *}$ & & & $-1.569 * * *$ & $-2.702^{* * *}$ & $-3.175^{* * *}$ \\
\hline & & & {$[0.452]$} & & & {$[0.488]$} & [0.429] & {$[0.386]$} \\
\hline \multirow[t]{2}{*}{$\Delta U^{*} \operatorname{Mob} 2$} & & & & -0.211 & & & & \\
\hline & & & & {$[0.342]$} & & & & \\
\hline \multirow[t]{2}{*}{$\Delta U^{*}$ Mob3 } & & & & $-0.984^{* *}$ & & & & \\
\hline & & & & {$[0.462]$} & & & & \\
\hline \multirow[t]{2}{*}{$\Delta U^{*}$ Age 2} & & & & & 0.056 & & & $-1.365^{* * *}$ \\
\hline & & & & & {$[0.385]$} & & & [0.490] \\
\hline \multirow[t]{2}{*}{$\Delta U^{*}$ Age 3} & & & & & 0.151 & & & $-1.928 * * *$ \\
\hline & & & & & {$[0.512]$} & & & [0.623] \\
\hline \multirow[t]{2}{*}{$\Delta U^{*}$ Age 4} & & & & & 0.279 & & & $-2.275 * * *$ \\
\hline & & & & & {$[0.604]$} & & & {$[0.766]$} \\
\hline \multirow[t]{2}{*}{$\Delta U^{*}$ Age 5} & & & & & 0.869 & & & $-1.791 * * *$ \\
\hline & & & & & {$[0.647]$} & & & {$[0.275]$} \\
\hline \multirow[t]{2}{*}{$\Delta U^{+*} \operatorname{Mob} 2$} & & & & & & -0.42 & & \\
\hline & & & & & & {$[0.400]$} & & \\
\hline \multirow{2}{*}{$\Delta U^{+*}$ Mob3 } & & & & & & $-2.084^{* * *}$ & & \\
\hline & & & & & & [0.369] & & \\
\hline \multirow[t]{2}{*}{$\Delta U^{+*}$ Age 2} & & & & & & & $1.710^{* * *}$ & $3.151^{* * *}$ \\
\hline & & & & & & & {$[0.361]$} & [0.627] \\
\hline \multirow[t]{2}{*}{$\Delta U^{+*}$ Age3 } & & & & & & & $2.067^{* * *}$ & $4.243^{* * *}$ \\
\hline & & & & & & & {$[0.552]$} & [0.867] \\
\hline \multirow[t]{2}{*}{$\Delta U^{+*}$ Age 4} & & & & & & & $2.407 * * *$ & $4.982^{* * *}$ \\
\hline & & & & & & & {$[0.646]$} & [1.052] \\
\hline \multirow[t]{2}{*}{$\Delta U^{+*}$ Age 5} & & & & & & & $3.484^{* * *}$ & $5.498^{* * *}$ \\
\hline & & & & & & & {$[0.608]$} & [0.694] \\
\hline$R^{2}$ & 0.077 & 0.077 & 0.129 & 0.089 & 0.083 & 0.157 & 0.203 & 0.247 \\
\hline
\end{tabular}

Notes: The coefficients reported result from the second-stage regression, which used the estimated coefficients of year dummies in a wage growth equation (the first stage). In the second stage, the year dummies are regressed on the variables listed plus a trend. 450 observations are used. $\Delta U$ denotes the change in the unemployment rate with respect to the previous year; $\Delta U^{+}$denotes the interaction between $\Delta U$ and a dummy variable taking value one in years in which the unemployment rate increases; Fem is a dummy for women; Mob2 is a dummy for movers within a firm; Mob3 is a dummy for movers between firms; and Age 2 denotes workers aged between 25 and 34 (Age3 35 and 44; Age 4 - 45 and 54; Age 5 - 55 and 64). Significance levels: *: 0.10; **: 0.05; ***: 0.01. Robust standard errors. 
Table A.1: Descriptive statistics - First stage data

\begin{tabular}{|c|c|c|c|c|}
\hline Mover Type & Variable & Mean & (Std. Dev.) & $\mathbf{N}$ \\
\hline \multicolumn{5}{|c|}{ Stayers in the same job level and firm } \\
\hline & Age & 38.46 & $(10.87)$ & 13866171 \\
\hline & Female & 0.39 & $(0.49)$ & 13866171 \\
\hline & Schooling & 6.8 & $(3.68)$ & 13665123 \\
\hline & Tenure & 10.59 & $(8.80)$ & 13804805 \\
\hline & Job level & 5.16 & $(1.44)$ & 13636125 \\
\hline & Log total wage & 1.42 & $(0.61)$ & 13866171 \\
\hline & Log basic wage & 1.22 & $(0.52)$ & 13866092 \\
\hline & Change in log total wage & 0.04 & $(0.28)$ & 13866171 \\
\hline & Change in log basic wage & 0.03 & $(0.21)$ & 13866038 \\
\hline & Firm size & 1378.82 & $(3886.41)$ & 13866171 \\
\hline & Year & 1996.56 & $(5.16)$ & 13866171 \\
\hline \multicolumn{5}{|c|}{ Stayers in a different job level but in the same firm } \\
\hline & Age & 35.65 & $(10.95)$ & 2368861 \\
\hline & Female & 0.4 & $(0.49)$ & 2368861 \\
\hline & Schooling & 7.74 & $(4.06)$ & 2322208 \\
\hline & Tenure & 8.4 & $(7.93)$ & 2358884 \\
\hline & Job level & 4.9 & $(1.79)$ & 2173521 \\
\hline & Log total wage & 1.45 & $(0.64)$ & 2368861 \\
\hline & Log basic wage & 1.27 & $(0.58)$ & 2368852 \\
\hline & Change in log total wage & 0.08 & $(0.31)$ & 2368861 \\
\hline & Change in log basic wage & 0.07 & $(0.24)$ & 2368847 \\
\hline & Firm size & 1107.99 & $(3542.38)$ & 2368861 \\
\hline & Year & 1996.49 & $(5.2)$ & 2368861 \\
\hline \multicolumn{5}{|c|}{ Movers to a different firm } \\
\hline & Age & 31.99 & $(9.5)$ & 1157498 \\
\hline & Female & 0.36 & $(0.48)$ & 1157498 \\
\hline & Schooling & 7.43 & $(3.77)$ & 1117909 \\
\hline & Tenure & 0.28 & $(0.61)$ & 1156813 \\
\hline & Job level & 5.51 & $(1.59)$ & 1123001 \\
\hline & Log total wage & 1.29 & $(0.56)$ & 1157498 \\
\hline & Log basic wage & 1.1 & $(0.49)$ & 1157494 \\
\hline & Change in log total wage & 0.07 & $(0.49)$ & 1157498 \\
\hline & Change in log basic wage & 0.07 & $(0.35)$ & 1157488 \\
\hline & Firm size & 439.6 & $(1600.11)$ & 1157498 \\
\hline & Year & 1997.18 & $(5.04)$ & 1157498 \\
\hline
\end{tabular}

Notes: Author's calculations based on the complete 'Quadros de Pessoal' data. 'Schooling' measured in number of years of schooling. 'Tenure' measured in years. 'Job level' is measured from 1 (highest level - top managers) to 9 (lowest level - apprentices). All wages are real hourly wages. 'Firm size' measured in number of employees. The data refer to period $t$ and all workers are also observed in period $t-1$. $t$ ranges from 1987 to 2004 . See main text for more details. 